\title{
Grundtvigs prædiken i Vartov 1. maj 1844
}

\section{Af Jette Holm og Elisabeth A. Glenthøj}

Grundtvig prædikede sidste gang i Vartov onsdag den 1. maj 1844, inden han syg rejste ud til sine præstevenner på Sjælland 3. til 23. maj. Prædikenen har ikke tidligere været trykt. Den bringes her dels som bilag til Christian Thodbergs artikel om Grundtvigs krise i 1844 i dette nummer af Grundtvig-Studier, dels som en prøve på prædikenerne fra Vartov, som udkommer i disse år. De første 3 bind prædikener (183942) med kommentarbind udkom i 2003 på Forlaget Vartov, den næste pakke med endnu 3 årgange prædikener (1843-45) med kommentarbind forventes at være klar til trykkeriet i løbet af foråret 2006.

Elisabeth A. Glenthøj, Jette Holm og Christian Thodberg.

I J. $\mathbf{N}$.

Onsdagen 1ste Mai 1844

Rom X. 5.

Moses beskriver den Retfærdighed af Loven saa, at det Menneske, som giør disse Ting, skal leve ved dem; men Retfærdigheden af Troen taler saaledes: sig ikke i dit Hjerte: hvem vil fare til Himmels, det er, at hente Christus ned, eller hvem vil fare til Afgrunden, det er at hente Christus op fra de Døde! men hvad siger Den? Ordet er dig nær, i din Mund og i dit Hjerte, det er det Troens Ord, som vi udraabe; thi naar du med din Mund bekiender den Herre Jesus, og du troer i dit Hjerte, at Gud opreiste ham fra de Døde, da skal du blive salig, thi med Hjertet troer man til Retfærdighed og med Munden bekiender man til Salighed. Derfor siger Skriften, hvo som troer paa Ham, skal ikke beskæmmes! thi der er ingen Forskiel paa Jøde og Grceker, da han selv er Alles Herre, rig nok til alle dem, som Ham paakalde, saa Enhver, som paakalder Herrens Navn, skal blive salig! Men, hvordan skulde de paakalde En, paa Hvem de ikke troer, eller troe paa En, om hvem de ikke har hørt, eller høre uden hvad der udraabes, og hvordan skulde de udraabe, som ikke udsendtes, som skrevet staaer: hvor deilige ere deres Fødder, som forkynde Fredens glade Budskab, forkynde 
Godheds Evangelium! Men de var ikke alle Evangelium lydige, thi Esaias siger: hvo har troet vore Øren! altsaa er Troen af Hørelsen, Guds Ords Hørelse nemlig.

Ch. V. disse Apostelen Pauli Ord faldt mig stærk paa Sinde, da jeg i min Ungdom, for en Menneske-Alder siden, begyndte at tænke alvorlig paa Guds Ords Forkyndelse og Salighedens Vei, og det stod da strax soleklart for mig, at hvad Apostelen vilde sige, var kortelig dette, at Han og Hans Med-Apostler havde forkyndt et Guds Ord, som kunde og som skulde troes og bekiendes, og naar det skedte, gjorde alle de Troende retfærdige for Gud og Saligheden visse.

$\mathrm{Nu}$ vil Faa eller Ingen nægte, det er saa, men dengang havde denne jævne Sandhed hele Verden, især denne Verdens Vise og Lærde imod sig, saa, da jeg spurgde høit: hvi er Herrens Ord forsvundet af Hans Huus, da reiste Verden sig imod mig som en Misdæder, og jeg maatte være belavet paa at trodse den i en Kamp paa Liv og Død om det gamle Guds Ord, hjertelig Troe derpaa, og frimodig Bekiendelse deraf, som jeg erklærede for den eneste ægte Christendom og for de himmelske Saligheds-Midler paa Jorden.

$\mathrm{Nu} \mathrm{m}$. V. denne gode Strid har jeg stridt og bevaret Troen, om jeg har fuldendt Løbet, det veed kun Gud, og det staaer i Hans Haand, men jeg skylder Ham og Sandheden og Herrens Menighed, som Han kiøbde med sit Blod, det Vidnesbyrd, at det var ikke mig, som gav Ordet, men Ordet, som gav mig Kraft til at stride og vinde, og at det var meget mere Troen, som bevarede mig, end mig, som bevarede Troen, kort sagt, at Alt, hvad jeg var som troende Christen og Guds Ords Tjener, det var jeg af Guds Naade, som jeg kun stræbde ei at tage forgiæves, men at benytte ærlig til egen og Andres Saliggiørelse i det Jesu Christi velsignede Navn, som er os dertil skænket og givet.

Det var langtfra, at det i Begyndelsen stod saa klart for mine Øine, som det staaer nu, hvad det er for et Troens og Bekiendelsens Ord, Apostelen gav det store Vidnesbyrd, at det giver hvert troende Hjerte Fred og Fyldestgiørelse, saa vi ikke spørge, hvem der vil hente os Herren, men føle, Han er os saa nær, som det Ord, Han har sendt os med sine Apostler, ligesaa nær vor Mund og vort Hjerte, som dette Ord; men altid var det dog et levende, lydeligt Guds Ord, Herrens og ikke vort eget, som jeg gav Vidnesbyrd, et Guds Ord altsaa, som alle Christne, baade Lærd og Læg, baade Vise og Uvise, maatte kiende, have, troe, elske, i Hjertet bevare tilfælles, og med Munden enstemmig bekiende, thi saaledes fandt jeg Guds saliggiørende Ord beskrevet i Skriften, og saaledes følde jeg Dets Kraft og Velsignelse i mit eget Hjerte.

Derfor blev jeg glad, som En, der finder et stort Bytte, ja, som den Kiøbmand, der ledte om ægte Perler og fandt en saa dyrebar, at Han 
solgde Alt, hvad han havde, og kiøbde den, da jeg i Morten Luthers Cathechismus, i de Christnes æl[d]gamle tre Troes-Artikler og BørneLærdom, og fremfor Alt i den fælles Troes-Bekiendelse ved Daaben, fandt det eneste $\mathrm{G}[\mathrm{uds}] \mathrm{O}[\mathrm{rd}]$, som alle Christne har hørt og enstemmig bekiendt, [det] Guds Ord, som alle Christne skal troe og bekiende, retfærdiggiøres og blive salige ved; thi nu kunde jeg klare det baade for mig selv og for Menigheden, at det var ikke mig selv, men Herren Jesus Christus, jeg forkyndte, ikke mit eget Paafund, eller min egen Skrift-Kundskab og Skrift-Klogskab, eller mine egne indvortes Følelser og Erfaringer, jeg kalder det Guds Ord, som er mægtigt til at saliggiøre Sjæle, men at det er et fælles Troens Ord, fra de hellige Apostlers Mund, hørt og bekiendt over hele Christenheden, vel skjult for de Lærde, men aabenbart for de Umyndige, et Saadant netop, som Apostelen beskriver i vor Text, hvilket ogsaa jeg byggede mit Saligheds-Haab alene paa, og gav villig mit ringe Vidnesbyrd.

See, derfor kan jeg nu rolig, naar Gud vil, fuldende min Tale og slutte mit Vidnesbyrd; thi jeg veed, at dette Troens Ord er Guds eget Vidnesbyrd om sin Søn, saa Enhver, som har dette Ord i sin Mund og i sit Hjerte, har, som Apostelen Johannes skriver, Guds eget Vidnesbyrd inden i sig, Guds Vidnesbyrd, at Han haver skænket os det evige Liv, og at dette Liv er i Hans Søn, Vorherre Jesus Christus, saa hvem der i Troen har Ham, har ogsaa Livet.

I denne Henseende er det aabenbar Naade af Gud, naar Han lader sit Ords Tjenere blive gamle og svage for Menighedens og for Verdens Øine, thi Han er ingenlunde en Herre, som bortkaster sine Tjenere i Alderdommens Tid, eller forlader os, naar vor Kraft forgaaer, vi findes neto[p] stærke i vor Sk[røbelighed], saa det bliver soleklart, vi trængte selv høilig til Gud og hans Ord for at holde os opreiste og stride den gode Strid, da først nødes Verden til at see, hvad der er Menigheden indlysende, at vi bære Klenodiet i Leerkar, saa den overvættes Kraft, som følger Ordet, er Guds og er ingenlunde af os. Og see, det er jo vort Hjertes Begiæring, naar vi talede, fordi vi troede, og troede, fordi vi følde, at kun Vorherre Jesus Christus har Fuldmagt paa Jorden til at forlade Synder og Magt til at retfærdiggiøre og saliggiøre dem, som troe og kalde paa Ham, ja, det er vort Hjertes Begiæring, at Troen og Tilliden i Salighedens Sag aldeles maa flytte fra os, som komme og forsvinde, blomstre og visne med Urterne paa Marken, flytte fra os og fæstes til det Guds Ord, som er mægtigt til at saliggiøre vore Sjæle, og som paa os har aabenbaret hele sin Kraft, i det vi gjordes dygtige deraf til den ny Pagts Embedsmænd, ikke Bogstavens, som ihjelslaaer, men Aandens, som giør levende, det levende Guds Ord, som varer evindelig. 
Og for at nu alle Christne maae vide, hvordan det gaaer til, at dette Troens Ord bliver levende for os og bliver, hvad Herren lovede de Troende, Kildespringet med de levende Vandstrømme i deres Bryst, da skal vi sige dem, det skeer ved Tilegnelsen, idet vi troe, at ligesom Herren siger os i Nadveren, det var for os, Han hengav sit Legeme og udøste sit Blod, saaledes blev Han ogsaa født af en Kvinde og gjorde alle sine Gierninger, opfyldte Kiærlighedens Lov for os, opstod for os fra de Døde, og gik kun i Forveien hjem til sin Faders Huus for at berede os Plads og sende os Faderens Aand, som følger med Hans Ord fra Slægt til Slægt, og ledsager de Troende til al Sandhed.

Ja m. V. ved denne Troe, Troen paa Herrens Ord og Faderens Aand, den Hellig-Aand, som altid følges ad, ved denne Tro bliver Ordet levende i os, og en Livskilde hos os, som aldrig udtørres, derved bliver det en Guds Kraft til Salighed for hver den, som troer.

Dette er det Klareste, jeg endnu kan sige om disse dybe Ting, og jeg vil slutte med Apostelen Pauli dyrebare Ord: jeg overlader eder, Medchristne, Brødre og Systre i Herren, til Gud, og til Hans Naades Ord, som er mægtigt til at opbygge eder og give eder Arv med alle Hans Hellige, thi I skal alle have Fællesskab med os og med Herrens Apostler, ligesom de og vi med dem, har Fællesskab med Faderen og med Hans Søn, Jesus Christus, i den Hellig-Aand; og dette Fællesskab har alle Troende i den Hellige Nadver, saavist som det er et Guds Ord til os alle: tager hen og æder, det er mit Legem! drikker alle heraf, det er den ny Pagts Kalk i mit Blod, som udgydes for eder til Syndernes Forladelse! Amen! i Vorherres Jesu Christi Navn Amen! 